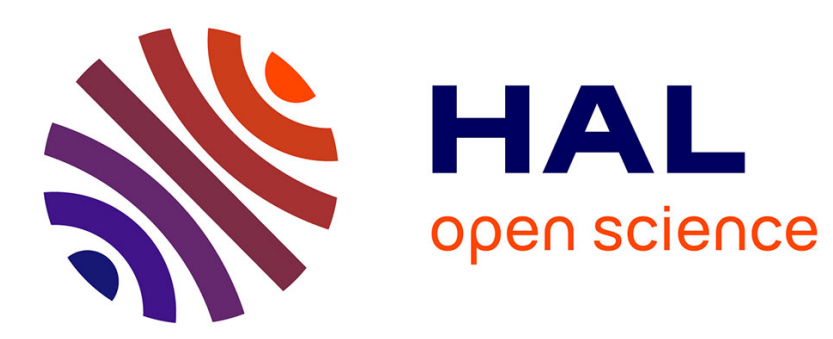

\title{
Can road stormwater ponds be successfully exploited by the European green frog (Pelophylax sp.)?
}

\author{
Antonin Conan, Jonathan Jumeau, Nathan Dehaut, Manfred Enstipp, \\ Jean-Yves Georges, Yves Handrich
}

\section{To cite this version:}

Antonin Conan, Jonathan Jumeau, Nathan Dehaut, Manfred Enstipp, Jean-Yves Georges, et al.. Can road stormwater ponds be successfully exploited by the European green frog (Pelophylax sp.)?. Urban Ecosystems, 2021, 10.1007/s11252-021-01129-z . hal-03364061

\section{HAL Id: hal-03364061 \\ https://hal.science/hal-03364061}

Submitted on 6 Dec 2021

HAL is a multi-disciplinary open access archive for the deposit and dissemination of scientific research documents, whether they are published or not. The documents may come from teaching and research institutions in France or abroad, or from public or private research centers.
L'archive ouverte pluridisciplinaire HAL, est destinée au dépôt et à la diffusion de documents scientifiques de niveau recherche, publiés ou non, émanant des établissements d'enseignement et de recherche français ou étrangers, des laboratoires publics ou privés. 


\section{Published in "Urban Ecosystems"}

\section{Can road stormwater ponds be successfully exploited by the European green frog (Pelophylax sp.)?}

Antonin Conan ${ }^{1,2} *$; Jonathan Jumeau ${ }^{2 \bullet}$; Nathan Dehaut ${ }^{1,2}$; Manfred Enstipp ${ }^{1}$; Jean-Yves Georges $^{1}$; Yves Handrich ${ }^{1}$

${ }^{1}$ Université de Strasbourg, CNRS, IPHC UMR 7178, F-67000 Strasbourg, France

${ }^{2}$ Conseil Départemental du Bas-Rhin, Place du Quartier Blanc, 67964 Strasbourg, Cedex 9, France

- Co-first authors

* Corresponding author: antonin.conan@iphc.cnrs.fr

\section{Abstract}

Stormwater ponds ("SWPs") are artificial roadside structures, conceived to retain and clean polluted runoff water, before its release to the environment. SWPs were not designed as suitable habitats for wildlife. However, SWPs in Europe are frequently used as breeding sites by amphibians, especially by the European green frog (Pelophylax sp.). Yet, the potential longterm effects of pollutants within SWPs on the populations of this species are unknown. In this study, we investigated the suitability of SWPs as a habitat for European green frogs living in Alsace, NE France, a region with a highly modified landscape that mainly consists of croplands with few natural wetlands remaining. We compared various biological indicators of individual health in 709 green frogs belonging to different life history stages, living in 9 semi-natural ponds (SNPs) and in 25 SWPs. There were no differences between these two pond types for most of the indicators investigated. However, juveniles had a lower body condition (-124\%) in SWPs, while adults were $8.3 \%$ larger and $41.4 \%$ heavier in SWPs. Based on these results, we suggest that SWPs are not a suitable habitat for the development of European green frogs (i.e. juveniles), but may serve as a substitute habitat for adults in a highly modified landscape with few natural wetlands remaining. SWPs may especially act as relay sites, allowing frogs to colonize relict wetlands.

Keywords: amphibians; fitness; ecological source; ecological trap; road ecology 
During the $20^{\text {th }}$ century, wetland areas have decreased globally by at least $64 \%$, making them the most threatened habitats (Davidson, 2014; Hassall \& Anderson 2015). Wetlands are destructed directly through urbanization and agricultural practices (Fischer \& Lindenmayer 2007; Van der Ree et al. 2015; Metcalfe et al. 2018) but also indirectly through chemical pollution of water and soil (e.g. agriculture \& road traffic; Mander \& Mitsch 2009; Van der Ree et al. 2015; Maxwell et al. 2016). For instance, polycyclic aromatic hydrocarbons (PAHs) from domestic heating emissions and heavy metals from road traffic contaminate wetlands (Finlayson-Pitts \& Pitts 1997; Alam et al. 2018). Nowadays, urban planning uses infrastructures such as stormwater ponds (SWPs, also referred to as retention ponds) to reduce the pollution impacts from road water runoff to the environment (EPA 2009). In fact, SWPS are designed to collect, regulate, store and clean up runoff water, before its release to the environment (EPA 2009). Although the water in SWPs is polluted, especially by PAHs, heavy metals and salt (Gallagher et al. 2014; Snodgrass et al. 2017), some studies have shown that SWPs are frequently colonized by fauna and that amphibians in particular inhabit them (Scher et al. 2004; Brand \& Snodgrass 2010; Le Viol et al. 2012; Hassall \& Anderson 2015; Jumeau et al. 2020). Apart from studies indicating a low tadpole survival in SWPs (Dorchin \& Shanas 2010; Sievers et al. 2018), overall, little is known about the suitability of these sites for amphibian populations.

All amphibians share a common bimodal life cycle, consisting of seasonally alternating terrestrial and aquatic phases. This complex life cycle exposes amphibians to different environmental stressors throughout the year. After the winter, they move from their terrestrial wintering area to their aquatic breeding site, causing mass migrations that often lead to massive roadkill (Cushman 2006; Joly 2019). However, roadkill is certainly not the only threat these amphibians face. Especially in developed and industrialized regions, amphibians encounter numerous threats. One of the biggest contributor to amphibian declines is human land use that leads to habitat destruction and the isolation of populations (Gibbons et al. 2000; Stuart et al. 2004; Catenazzi 2015). Amphibians are also impacted by the introduction of invasive species that compete with local species (Gibbon et al. 2000; Falaschi et al. 2020) and that might lead to disease proliferation (Gibbons et al. 2000; Stuart et al. 2004; Duffus \& Cunnngham 2010; Kik et al. 2011). Emerging viral and fungal pathogens affect amphibians worldwide (Price et al. 2014; Catenazzi 2015). Moreover, amphibians, like most animal and 
plant species, are strongly impacted by global warming (Gibbon et al. 2000; Falaschi et al. 2020) and pollution (Salice 2012; Dirzo et al. 2014; Catenazzi 2015). Given their permeable skin, amphibians are especially vulnerable to pollutants present in the water (Wilbur 1980; Miaud et al. 2000; Quaranta et al. 2009). Elevated concentrations of PAHs and heavy metals have been reported to directly and indirectly impact amphibians across various temporal scales. For instance, aforementioned pollutants have been shown to cause disorders during embryonic development (Bryer et al. 2006; Brand et al. 2010), body malformations that result in a greater fluctuating asymmetry (Guo et al. 2017) and, ultimately, reduce survival (Dorchin \& Shanas 2010; Gallagher et al. 2014). Thus, the SWPs, containing polluted water, may negatively affect amphibian reproduction, which is of great concern for one of the most threatened vertebrate taxa in the world (Stuart et al. 2004).

Amphibian reproduction and population trends can be affected by factors other than pollution. For example, aquatic vegetation (e.g. macrophytes and algae) can have a positive effect by providing ideal breeding sites and shelter for amphibians, and by supplying additional food for their larvae. Predation by fish and interspecific competition may have negative effects on the entire amphibian community (Hamer \& Parris 2011; Martins et al. 2013; Oertli \& Parris 2019). Additionally, different abiotic characteristics of the ponds that amphibians use, regardless if they are semi-natural or artificial, may affect their suitability for amphibians (Sievers et al. 2019). For example, the presence of gently sloping areas $\left(<30^{\circ}\right)$ seems to be most favourable for amphibians (Lesbarrères \& Lodé 2002). In artificial ponds (e.g. SWPs), the presence of specific structures, such as oil removers, found on the SWP banks, where they skim the surface water and remove oil and other organic matter, have recently been implicated to create death traps for amphibians (Jumeau, personal communication). Finally, beside the pond itself, the surrounding landscape is of great importance for amphibians, not only during their movement to/from the breeding pond, but also after reproduction, since most amphibians overwinter on land. For instance, amphibian movements can be disrupted in highly modified landscapes that are mainly composed of croplands and roads. Moreover, species requirements differ, so that the quality rating of the landscape surrounding the breeding sites depends on the ecological niche and habitat use of the species in question (Indermaur et al 2009). A number of important functions have to be provided by the landscape surrounding the breeding site. Firstly, the provision of refuge areas 
to avoid predators but also for thermoregulation (microclimate; Schwarzkopf \& Alford 1996; Seebacher \& Alford 2002). A sufficient prey availability is essential for survival and, especially, successful breeding (Waelti \& Reyer 2007), particularly if the access to alternative ponds, located in more favourable habitats, is reduced because of environmental degradation and fragmentation (Cushman 2006). In such altered landscapes, natural and semi-natural ponds have almost disappeared, increasing isolation of the few breeding sites and, thus, decreasing amphibian population viability (Joly 2019; Cayuela et al., 2020).

\section{Research objectives}

The current investigation is part of a long-term study on the ecological role and importance of stormwater ponds for amphibian conservation. Here, we investigated the suitability of SWPS as a habitat for amphibians. Whereas previous studies mainly focused on population and community level characteristics (e.g. species richness; Le Viol et al. 2012; Jumeau et al. 2020), we used a qualitative approach by assessing individual health criteria (Pulliam 1988; Runge et al. 2006; Furrer \& Pasinelli 2016). In our study, we compared fitness indices of European green frogs (Pelophylax sp.) living in SWPs with fitness indices of frogs living in semi-natural ponds (SNPs), the latter being the control group. Fitness was assessed using two commonly used indicators of fitness: (1) the body condition index ( $\mathrm{BCl})$, which refers to the size-corrected body mass of an animal and has been used as a proxy of individual energy reserves and fitness in many species (e.g. amphibians, reptiles, birds and mammals; Green 2001; Schulte-Hostedde et al. 2005) and (2) the fluctuating asymmetry index (FA), which reflects minor deviations from a perfect bilateral symmetry of animals (Palmer \& Strobeck 1986; Leung et al. 2000). FA is used as an indicator of developmental stability (Guo et al. 2017; see also Breno et al. 2013 for mammals), past exposure to stressors, and fitness in amphibians (Costa \& Nomura 2016; Guo et al. 2017; Zhelev et al. 2019). Taking into account previous studies concerning SWPs (Snodgrass et al. 2008; Dorchin \& Shanas. 2010; Sievers 2017), we predicted that individuals found in SWPs should have a lower health index (i.e. body condition) than those found in SNPs. We then investigated the environmental parameters associated with individual SWPs (e.g. biotic/pollutant/conception/landscape; Tab. 1) and linked them with the indicators of individual frog fitness. We predicted that environmental parameters of individual SWPs would affect the fitness of green frogs.

\section{Materials and Methods}




\subsection{Study area and sites}

128 The study was carried out during the summer of 2019 in the agricultural plain of Bas-Rhin, 129 Alsace, NE of France (as described in Jumeau, 2020). This area consists of an extensive 130 agricultural landscape, where 87 stormwater ponds (SWPs) and 41 semi-natural ponds (SNPs) 131 have been identified and geolocated using data from the French National Geographic 132 Institute (https://www.geoportail.gouv.fr). All SWPs were artificial ponds, surrounded by 133 fences to exclude large fauna and in $80 \%$ of the cases also small fauna (e.g. rodents), while all 134 SNPs had no fences. However, most of the small fauna fences were in poor condition, 135 enabling small fauna to enter SWPs. Only ponds with safe access, relatively shallow depth and 136 a sparse surrounding vegetation (enabling field prospection by foot) were considered in the 137 present study.

138 Hence, 25 SWPS and 9 SNPs were included in the current study (Figure 1). Among the 25 SWPS, 5 were composed of two basins (one for water-infiltration and one for waterretention). In the case of dual ponds, we only captured individuals from the retention basin, which contains water throughout the year. Furthermore, 9 out of 25 SWPs contained a specific structure to skim oil from the road water run off (oil remover). It consists of a concrete drainage, positioned at a $\sim 45^{\circ}$ angle, covered with a metal grid that skims the water surface, once it has reached the lower rim of the structure. However, amphibians may be carried inside this structure (depending on the nature of the grid) with the water flow and become trapped. Potential effects of these structures on frog biometrics/body condition were investigated.

\subsection{Study animals}

We used the European green frog as our model species, which is the most abundant species encountered in the SWPs of the study area (Jumeau et al., 2020). In Alsace, all species of the Pelophylax complex are locally classified as 'Least Concern' on the Alsacian Red List (Pelophylax kl. esculentus, Pelophylax ridibundus), with the exception of Pelophylax lessonae, classified as 'Near Threatened' (BUFO 2014).

From June to August 2019, green frogs were collected by hand during nocturnal patrols of the above-mentioned 25 SWPs and 9 SNPs. All visits to SWPS and SNPs were conducted at random and mean visiting date (11/07/2019) did not differ between pond type. Individual 
frogs were located by listening for singing males and approached using headlights, to allow hand capture with telescopic nylon nets. Captures were simultaneously conducted by two to three persons, each person having a bucket to store the individuals until the time of body measurements. To minimize the impact of our study on amphibians, a maximum of 30 individuals were captured per site and each site was sampled only once. This protocol limited the disturbance but also avoided the potential recapture of individuals.

All individuals captured in a given water pond were placed in a plastic bag and weighed. The sex of adult frogs was determined by the presence of nuptial pads and vocal sacs in adult males (Duellman \& Trueb 1994). For the immatures (i.e. $<25 \mathrm{~g}$ ), we distinguished two groups according to size: sub-adults (body length $\geq 34 \mathrm{~mm}$ ) and juveniles (body length $<34 \mathrm{~mm}$, see Results). We did not determine the exact species, to avoid identification mistakes between species of the Pelophylax complex, which are hard to identify in the field (Patrelle et al. 2011). Body mass $(B M)$ was measured with a spring balance $\left( \pm 0.3 \mathrm{~g}\right.$, Pesola ${ }^{\circledR}$, Schindellegi, Switzerland) for individuals $\geq 25 \mathrm{~g}$ (thereafter referred to as adults i.e. sexually mature; Kyriakopoulou-Sklavounou \& Loumbourdis, 1990) and with a precision scale ( $\pm 0.01 \mathrm{~g}$, AromaZone ${ }^{\circledR}$, France) for juveniles and sub-adults $(<25 \mathrm{~g}$; i.e. sexually immature). Body length measurements were conducted using an electronic calliper $(0-150 \pm 0.03 \mathrm{~mm}$, Tesa technology ${ }^{\circledR}$, Renens, Switzerland). We measured body length from the snout to the tip of the ischium (thereafter referred to as SVL for Snout-Vent Length) and the length of the left and right forearms and tibias. After the measurements, individuals were kept shortly in a second bucket, before being released at the exact location of their capture.

To prevent the spreading of pathogens such as Batrachochytrium sp., we used single-use gloves for all handlings, that were replaced between sites. Boots, nets and buckets were disinfected with a Virkon ${ }^{\circledR}$ solution between sites (Miaud 2014). All handling procedures were authorized by the "Arrêté Préfectoral n²019-DREAL-EBP-0030".

\subsection{Fitness indicators}

We used two indices of individual fitness. (1) A body condition index (BCl) was calculated following Green (2001), using the individual residuals of the linear regressions between $\operatorname{Ln}(B M)$ and $\operatorname{Ln}(S V L)$ for each group (adult females, adult males, sub-adults and juveniles). Fluctuating asymmetry (FA) was calculated for the length of forearms and tibias, according to 
187 Palmer and Strobeck (1986): $=\frac{a b s\left(C_{l}-C_{r}\right)}{\text { mean }\left(C_{l}, C_{r}\right)}$, where "abs" is the absolute difference between $C_{1}$ 188 and $C_{r}$, and $C_{I}$ and $C_{r}$ are the length of the left and right forearms or tibias, respectively. In 189 addition to these two indices, we also calculated the sex-ratio (SR) for each site as the number 190 of males divided by the total number of males and females collected.

\section{$191 \quad$ 2.4. Environmental parameters of stormwater ponds}

192 We used 23 environmental parameters, based on the landscape surrounding the pond (i.e. 193 pond conception, biotic conditions and pollution levels; Tab.1), to investigate potential 194 relationships with fitness indicators. Unfortunately, because of the lack of data concerning

195

196

197

198

199

200

201

202

203

204

205

206

207

208 pollution levels, such analysis was not possible for the SNPs. For the SWPs pollutants, we only retained concentrations of dissolved nitrogen, chlorine and copper in our characterization, since they were the only pollution parameters that had been consistently recorded in most of the SWPs (14 ponds for nitrogen and copper, 15 ponds for chlorine; Jumeau et al. 2020). Consequently, environmental parameters were investigated in 17 out of 25 SWPs. The surrounding landscape of each of the 17 SWPs was characterised in terms of landscape elements based on the "Coopération pour I'Information Géograhique en Alsace" database (with a precision of 1:10 000, CIGAL 2018). The presence and surface area of crop fields, forests, grasslands, and wetlands, were calculated within a 500 m radius (hereafter referred to as 'nearby environment') and within a $5000 \mathrm{~m}$ radius (referred to as 'distant environment') around each SWP (Smith \& Green 2005), using geographical information system software (QGIS v3.10, Development Team, 2020). For the wetland elements, we distinguished important wetlands from ordinary wetlands based on the presence of an exceptional biodiversity in important wetlands (Agence de l'Eau Rhin-Meuse, DREAL 2016). Due to strong statistical dependencies between parameters of the nearby environment, only the presence/absence of each element was used for these parameters. Some landscape variables such as moorlands and orchards were not included in our analysis because they were not present within the $5000 \mathrm{~m}$ radius for many SWPs.

\subsection{Statistical analyses}

Sexual dimorphism in body length (SVL) and body mass (BM) in each of our 34 study sites (SWPs and SNPs) was tested using a Wilcoxon test. An analysis of variance (ANOVA), based on Linear Mixed Models (LMM) with site as random factor, was used for comparing SVL, BM, BCl 
and the two FA indices (forearms and tibias) between SWPs and SNPs for each individual group (males/females/sub-adults/juveniles). To obtain a Gaussian distribution, a BoxCox transformation was applied to FA indices. The relationships between SWP environmental parameters and SVL, BM, BCl and FA indices were tested in males only, using Linear Model (LM) based ANOVAs ( $n=17$ SWPs), since males were the only group that was present in sufficiently large numbers $(n \geq 6)$ at all ponds. Each environmental parameter for the SWPs was standardized before analysis. Collinear environmental parameters were identified and removed using Spearman tests. All statistical analyses were conducted using R (v3.5.3, RStudio v1.2.1335, R Core Team, 2020) and all figures were plotted with GraphPad Prism 8.2.1 (San Diego, California, USA). Each model was selected by a BIC bidirectional elimination procedure. Results are shown as mean \pm SEM with a statistical significance threshold of $5 \%$ (* for $p<0.05, * *$ for $p<0.01$ and $* * *$ for $p<0.001$ ). The GLM estimates are indicated as " $\beta$ ".

\section{$\underline{\text { 3. Results }}$}

A total of 709 individuals was captured in 25 SWPs ( $N=509$ individuals) and 9 SNPS ( $N=200$ individuals). A rank-frequency histogram of individual body length (see suppl. figure 1) and body mass showed a clear separation within our immatures (i.e. $<25 \mathrm{~g}$ ), allowing us to distinguish two groups of immatures: sub-adults (body length $\geq 34 \mathrm{~mm}$ ) and juveniles (body length $<34 \mathrm{~mm}$ ). The sampled population was composed of 393 males, 127 females, 112 subadults, and 77 juveniles. On average, $20.3 \pm 1.5$ individuals were captured per site (range for males: 0 to 30; females: 0 to 14; sub-adults: 0 to 13; juveniles: 0 to 21). Since vocalizing males were easier to locate, the sex ratio of captured individuals was biased towards males. However, this sampling bias was identical for both pond types.

\subsection{Body length, body condition and fluctuating asymmetry}

There was a significant sexual dimorphism for body length and body mass of adult frogs in both SWPS and SNPs. Females were, on average, about 10\% longer and $40 \%$ heavier than males (body length: SWPs: $W=4750, p<0.01$ and SNPs: $W=5778, p<0.01$; body mass: SWPs: $W=4463.5, p<0.01$ and SNPs: $W=5778, p<0.01 ;$ Tab. 2, Fig. 2A \& 2B).

Adult individuals from SWPs were significantly larger $\left(+6.6 \%\right.$ for the males $\chi^{2}=5.76, p<0.05$, $+12 \%$ for females $\left.\chi^{2}=3.98, p>0.05\right)$ and heavier $\left(+27.5 \%\right.$ for the males $\chi^{2}=6.04, p<0.05,+40.8 \%$ for females $\left.\chi^{2}=5.18, p<0.05\right)$ than individuals from SNPs (Tab. 3, Fig. 2A \& B). Conversely, 
juveniles were smaller in the SWPs when compared with the SNPs $\left(-10.4 \%, \chi^{2}=5.12, p<0.05\right.$;

Tab. 3), while body mass did not differ between pond types (Tab. 3). Lastly, the size and body mass of the sub-adult frogs did not differ between pond types ( $p>0.05$ Tab. 3).

250

251

252

253

254

255

256

257

258

259

260

261

262

263

264

265

266

267

268

269

270

271

272

273

274

275

276

Because of this sexual dimorphism in body length and body mass, the body condition index $(\mathrm{BCl})$ was calculated for each sex and group, separately. Our analysis showed a significantly lower $\mathrm{BCl}$ in juveniles from SWPs, when compared with individuals from SNPS $\left(-124 \% \chi^{2}=5.97\right.$, $\mathrm{p}=0.01$; Tab. 3). By contrast, there were no significant differences in $\mathrm{BCl}$ for the other groups (males, females, sub-adults) between SWPs and SNPs ( $p>0.05)$. In addition, there were no significant differences in fluctuating asymmetry between individuals from SNPs and SWPs for any of the investigated groups ( $p>0.05 ;$ Tab. 2 ).

3.2. Relationship between environmental parameters of SWPs and male green frog biometrics Despite the high variability for the concentration of the different pollutants analysed at the SWPs (coefficient of variability $>40 \%$ ), we found no significant relationship between any of the pollutants at SWPs included in the analysis (dissolved nitrogen, chlorine, copper) and the biometric variables recorded in adult male green frogs ( $p>0.05)$. Model analysis showed that adult male biometrics were correlated with landscape parameters, whereby larger frogs were found in SWPs surrounded by a greater proportion of cropland and forested areas within a $5000 \mathrm{~m}$ radius $(\beta=4.92, p<0.05 ; \beta=4.12, p<0.05)$. By contrast, smaller frogs were found in SWPs surrounded by a greater proportion of important wetlands on the same spatial scale $(\beta=-2.93, p<0.05)$. Adult male body condition index $(\mathrm{BCl})$ at the SWP was negatively correlated with the surface area of grassland fields $\left(\beta=1.2^{\mathrm{E}-2}, p<0.01\right)$ within a $5000 \mathrm{~m}$ radius. The $\mathrm{FA}$ based on forearm-length was negatively correlated with the surface area of grassland and important wetlands within a 5000m radius (Tab. 4). By contrast, the FA based on Tibia-length was not related to any of the characteristics of the SWPs tested in this study, as the BIC selection did not retain any relevant variables (i.e. FA tibias $\sim$; Tab. 4). Finally, male $\mathrm{BCl}$ was lower $(-286 \%)$ in SWPs equipped with an oil remover, when compared with SWPs without such a device ( $F=12.8, d=1, p<0.01 ;$ Tab. 4).

\section{Discussion}



latest designs often include additional elements to achieve this, such as oil removers. As such, SWPs are likely more polluted than the surrounding areas. Accordingly, our initial hypothesis was that SWPs are not a suitable habitat for wildlife, including the European green frog. Our results show that adult green frogs captured at SWPs were larger and heavier, but not in a better body condition, than those captured at SNPs. Juveniles, captured at SWPS, were smaller and their body condition was lower than in juveniles captured at SNPs. Hence, our results only partially support our original hypothesis.

We caught significantly more males than females at both pond types. Such an unbalanced sex ratio during capture has been reported previously for green frogs (Loman \& Madsen 2010; Green 2013) and also for other amphibian species (Wells 1977; Loman \& Madsen 2010; Grayson et al. 2012; Green 2013). A possible explanation might be that male amphibians actively search for females, while females typically hide after spawning (Wells 1977). Accordingly, males are more conspicuous (also given their vocal behaviour) and more susceptible to capture, when compared with females. Apparently, the situation at SWPs does not differ in that respect from natural ponds.

\subsection{Body size}

295 Body size is a strong driver of reproduction, leading to sexual dimorphism in many taxa (Masello \& Quillfeldt 2003; Baird et al. 2007; Whitman 2008). This is the case in amphibians, where reproduction is explosive, with females laying hundreds, if not thousands of eggs in one time. Consequently, most amphibians show sexual dimorphism, with females being larger than males, as is the case for green frogs (Shine 1979). Our results on adult body size show that female European green frogs were on average $8.3 \%$ larger and $41.4 \%$ heavier than males, which is consistent with previously reported values (Shine 1979). Females were larger and heavier in SWPS than in SNPS, leading to an even more pronounced female-biased dimorphism in SWPs. While this might seem counterintuitive, a larger size at the SWPS might be related to a greater food availability for individuals. Sievers et al. (2018) found that the tadpoles of frogs inhabiting more polluted stormwater wetlands survived less well but also reached metamorphosis earlier and at a larger size than at less polluted sites. They attributed 

the larger tadpole size to a greater food availability for surviving individuals, due to the combined effects of a higher mortality (density-dependent effects; Berven \& Gill 1983; Semlitsch et al. 1988) and eutrophication. Presumably, individuals that are larger during metamorphosis will become larger adults, as has been found for a number of salamander and frog species (Berven \& Gill 1983; Semlitsch et al. 1988). However, the larger body size of adult frogs captured at the SWPs, despite their similar body condition with adults from the SNPS, might have also been caused by a difference in age. Hence, the larger individuals captured at the SWPS may have been older than the smaller individuals captured at the SNPS. The skeletochronology approach could be used to test this hypothesis (Guarino et al. 1995). Older populations at the SWPs may result from a potentially lower mortality at such artificial sites, due to a reduced predation pressure, either because of negative effects of road density on predator numbers and activity (i.e. 'predation release hypothesis'; Downing et al. 2015) or because of predator exclusion via fences. The latter may limit the entrance of some amphibian predators, such as mustelids (Parris 2006; Otero et al. 2018) or fish that might be introduced by other species. Similarly, fences might limit frogs to disperse from the SWPs, resulting in a longer residence time, which might lead to older populations at SWPs, when compared with SNPs. Behavioural studies are needed to assess the capabilities of green frogs to pass fences surrounding SWPS.

Last but not least, the differences in body size we found between green frogs captured at SNPs and at SWPs may also be related to a potential species difference. The European green frog complex (the Pelophylax complex) includes different species (Pelophylax kl. esculentus, Pelophylax ridibundus, and Pelophylax lessonae), which are hard to differentiate in the field (Patrelle et al., 2011). For instance, Pelophylax lessonae can be morphologically smaller than the two other species and is more frequently found in (semi-)natural environments than the other two species (Pagano et al. 2001). Accordingly, frogs captured in SNPs in our study may have been specimens of the smaller Pelophylax lessonae. Unfortunately, we could not conduct any genetic or further morphological analyses, which would have allowed a precise determination. 
Despite the above-mentioned differences in body size and body mass between green frogs captured at SWPS and at SNPs, we found no differences in body condition or in fluctuating asymmetry between green frogs (adult males/females and sub-adults) captured at both pond types. Yet, juveniles captured at SWPs had a lower BCl and were also smaller than those captured at SNPS. A smaller body size and a lower body condition in juveniles of the SWPS suggest that they underwent an earlier metamorphosis and/or were smaller at metamorphosis. An earlier metamorphosis of frogs at SWPs is supported by results from Snodgrass et al. (2008) and Dorchin \& Shanas (2010), that concern Anaxyrus americanus and Bufotes viridis, respectively.

If we neglect the possibility that frogs collected at both pond types belonged to different species of the green frog complex (see above) and apart from potential differences in population age, the similar BCl observed in sub-adults and adults at SWPs and SNPs might also be explained by the following scenarios: (1) Juveniles that encountered potentially lower trophic conditions at SWPs and that survived to become sub-adults and adults were able to compensate for this. (2) Alternatively, while trophic conditions between pond types differed for juveniles, this was not the case for adults and sub-adults.

Body condition $(\mathrm{BCl})$ is the most commonly used proxy of individual energetic reserves and fitness (Green 2001; Schulte-Hostedde et al. 2005). The lower $\mathrm{BCl}$ of juveniles that developped at the SWPs (embryonic development), and the similarity of the $\mathrm{BCl}$ observed in adult and sub-adult individuals caught at the SWPs and the SNPS, suggests that the artificial nature of SWPs did not affect the trophic conditions experienced after metamorphosis, but rather affected embryonic development. Previous studies have found a relationship between pollutant levels (e.g. heavy metals and pesticides) and body mass in amphibians, where a higher pollutant level is associated with a lower body mass (Egea-Serrano et al. 2012) and, consequently, lead to a reduced $\mathrm{BCl}$. In our study, pollutant levels were not measured for all SWPS sites and not at all for the SNPs sites. However, our assumption was that pollutant levels should be lower at the SNPS than at the SWPS. Despite this, we found no relationship between pollutant levels and biometric measurements ( $\mathrm{BCl}, \mathrm{FA})$. This could mean that any potential effects of pollutants investigated in this study on adult and sub-adult European green frogs might have been similar in both pond types. Given the relatively low pollutant level and/or the specific combination of pollutants, it is possible that they had no measurable 
368 effect on the biometrics of collected frogs. Alternatively, it is also possible that individuals that 369 were exposed to a greater (pollutant) stress level and, therefore, might have shown a lower $370 \mathrm{BCl}$ and a higher $\mathrm{AF}$ index, did not survive and were, consequently, not captured. However, 371 during our study, we did not find any dead individuals. The pollutant issue is further 372 complicated by species differences concerning the sensitivity to pollution (Katz 1975) and 373 further studies are urgently needed to address this issue. 
374 Fluctuating asymmetry (FA) has been proposed as a good indicator of past stressful periods 375 and of individual fitness in amphibians (Costa \& Nomura 2016; Guo et al. 2017; Zhelev et al. 376 2019). FA has, thus, been used to compare environmental quality of different habitats used 377 by amphibians (e.g. Guillot et al. 2016; Sievers 2017). Guillot et al. (2016) compared the FA in 378 common toads (Bufo bufo) that were captured in farmland areas and in forested areas, while 379 Sievers (2017) investigated FA in the common eastern froglet (Crinia signifera), living in different wetland habitats. Sievers (2017) reported significant differences in FAs (forearms and tibias) between individuals captured in habitats of contrasting quality, whereas Guillot et al. (2016) only reported differences using forearm FA (Fig. 3). In our study, FA calculated from forearms was higher than the FA calculated from tibias. However, we did not find differences between individuals captured at SWPs and at SNPs. Differences in FA between forearms and tibias may be explained by the difficulty to accurately measure forearm length in amphibians, given its considerably shorter length, when compared with the length of the tibia (e.g. in juveniles, forearm versus tibia length is on average $5.5 \pm 0.07 \mathrm{~mm}$ and $12.9 \pm 0.3 \mathrm{~mm}$, respectively). In addition, interpretation of FA also depends on the threshold value used to assign environmental quality for amphibians. Accordingly, we strongly encourage colleagues to carefully consider FAs based on forearm length, because measuring the forearms of living amphibians can lead to inaccurate measurements (Alford et al. 1999). Considering the limits of using forearm FA, the measurements must be replicated to estimate a measurement error (Alford et al. 1999; Sievers 2017). In addition, when a measurement concerns a short structure (e.g. forearm), the measurement error of the instrument (e.g. electronic calliper) must also be taken into account. Therefore, the use of a calliper to measure the forearms to obtain the FA is risky. A better approach might be to take an X-ray of the animal, to allow an a posteriori measurement on a computer (Breno et al. 2013).

The FA investigation of our study could not demonstrate a difference in developmental conditions for European green frogs at the two pond types investigated (Fig. 3). However, our investigation concerning the $\mathrm{BCl}$, clearly indicates such a difference (Tab. 3 ). There is a wide spectrum of tools available to assess individual health in amphibians. For example, corticosterone levels in the blood have been used to investigate potential stress effects associated with habitat fragmentation and temperature increase in common toads (Janin et al. 2011; Brischoux et al. 2018). Hematological parameters, such as leucocyte count and 
haemoglobin concentration have also been used for health assessment in the context of pollution effects on amphibians (Zhelev et al. 2018). While such parameters provide a clear answer when assessing individual health status, blood sampling requires skills, training and specific ethical authorisations. By contrast, biometric measurements are relatively easy to obtain.

4.3. Linking stormwater pond design and surrounding landscape with adult male $\underline{\text { biometrics }}$

When investigating the relationship between various environmental parameters and adult frog biometrics, our model did not retain any pollutant variables. Hence, with respect to the pollutants included in our analysis and the considered sampling period, we found no negative impact of SWP water on adult green frog biometrics. The most likely explanation is that all pollutant concentrations ( $\mathrm{Cu}=8.1 \pm 1.02 \mu \mathrm{g} / \mathrm{l}, \mathrm{N}=0.05 \pm 0.01 \mathrm{mg} / \mathrm{l}, \mathrm{Cl}=9.7 \pm 1.8 \mathrm{mg} / \mathrm{l}$ ) were well below reported sub-lethal concentrations for amphibians ( $\mathrm{Cu}=31.6 \mathrm{mg} / \mathrm{l}, \mathrm{N}=20 \mathrm{mg} / \mathrm{l}$, $\mathrm{Cl}=1721.4 \mathrm{mg} /$; jumeau et al. 2020). Hence, with respect to the pollutants investigated in our analysis, this confirms that SWPS and SNPs are not highly contrasted environments for European green frogs.

By contrast, we found a strong correlation between adult male green frog biometrics and landscape parameters. Frogs were larger in SWPs surrounded by a greater proportion of cropland and forests within a $5000 \mathrm{~m}$ radius. When SWPs were surrounded by a greater proportion of important wetlands, frogs were smaller. A size increase might be explained by the absence of alternative habitats such as wetlands, as suggested by the negative relationship between the size of individuals (SVL) and surrounding wetland surface area. The mechanism behind this might be that in the absence of sufficiently large wetlands, older individuals might stay at SWPs, rather than abandoning them and moving to nearby wetlands. A further mechanism that could be verified experimentally might be the increasing input of agricultural fertilizers into the environment $(\mathrm{N}, \mathrm{P}, \mathrm{K})$, which are known to favour the proliferation of aquatic vegetation (Taziki et al. 2015). Accordingly, eutrophication at SWPs surrounded by croplands might increase food availability to green frog larval stages. The quantity of proteins ingested (both vegetable and animal sources) has been shown to affect the growth rate and survival of tadpoles in several amphibian species (Martinez et al. 1993, 1996; Martins et al. 2013) and possibly also affects adult size. While, the effect of food 
availability on tadpole body-size has been shown, it would be interesting to use a semicontrolled approach (e.g. mesocosm), to investigate this effect throughout the different life history stages of individuals. Such an investigation might also be possible in the field, using capture-mark-recapture methods (Miaud et al. 1999).

Apart from the link between the surrounding landscape of SWPs and male green frog biometrics, we found that individuals caught at SWPs that were equipped with an oil remover had a body condition $\sim 3$ times lower than frogs caught at SWPs lacking such a device. We believe that in SWPs equipped with an oil remover some frogs are washed through the metal grid during an overflow and become trapped inside the concrete drainage when the water level falls below the rim of the skimmer. Hence, trapped frogs might only be able to escape during the subsequent overflow, which might occur within a few days, weeks or months (Jumeau, personal communication). These stochastic events obviously depend on the weather and the season. Unable to feed when trapped inside the concrete drainage, the effect on frog body condition is obvious.

Unfortunately, for the SNPs, a statistical analysis investigating the potential effects of the surrounding landscape on frog biometrics was not possible because of a too small number of animals in each category.

\section{Are SWPs a suitable habitat for the European green frog?}

In our study, the results obtained from juveniles are in line with previous studies. A number of studies argued that SWPS are poor quality habitats for amphibian development (i.e. embryonic development), leading to small size and a poor body condition in this group (Bishop et al. 2000; Brand \& Snodgrass 2010; Dorchin \& Shanas 2010; Sievers 2017). However, our results obtained from sub-adults and adults contrast with results from the juveniles. The lack of a difference between pond types with respect to body condition and fluctuating asymmetry in adult and sub-adult frogs does not support our original hypothesis of SWPs being an unsuitable habitat for these groups, nor would they appear to be less favourable than SNPS.

A number of factors might have contributed to the differences we found between juvenile and adult/sub-adult green frogs. First, the hatching place of sub-adult and adult green frogs 
caught during the study is uncertain so that animals might have moved more recently to the SWPs. Most green frogs spend nearly all their adult life in the vicinity of the pond where they hatched (Peter, 2001), for example at a neighbouring pond, except if pond access has been altered (e.g. landscape fragmentation), as is the case for most of the SWPs in our study. Hence, we do not know if the adult/sub-adult green frogs caught at the SWPs originated from there. By contrast, for the juveniles it is certain that they spent their entire developmental period at the capture site because in some individuals the tail had not been fully resorbed. This emphasizes the need to investigate the suitability of SWPs for green frogs, by comparing, in situ, growth and survival rates of tadpoles from SWPS and SNPS.

475 Second, our sampling might have coincided with a non-representative year, with less 476 pollution from the roads in the water of the SWPs than typical for the study area of Bas-Rhin. 477 According to the European Environmental Agency, an upgrading of combustion engines and 478 an improvement in anti-pollution technology has occurred during the last 20 years (EEA 479 2020). However, at the same time, agricultural pollution has continued to increase (Zabel et al. 2019). These developments were confirmed in a recent study conducted between 2015 and 2016 on 82 SWPs in the Bas-Rhin area (Jumeau et al. 2020). That study measured more than 20 different pollutants and found that their concentrations in these SWPs were below established sub-lethal thresholds for amphibians (Jumeau et al. 2020). In this context, the protocols used in most studies investigating the effects of pollutants in a habitat on amphibians do not reflect the actual conditions of a site in situ but are mostly conducted within the laboratory (Bishop et al. 2000; Brand \& Snodgrass 2010; Dorchin \& Shanas. 2010). Studying the condition of individuals (e.g. BCl reflecting fitness) at a particular site, should better reflect the effects of the concerned environment on amphibians. Indeed, SWPs are not only structures that retain road pollutants. Instead, a complex set of factors, existing at these SWPs and their synergistic or opposing interactions can lead to positive or negative effects on the individuals that live at these sites.

492 Our study focused on the European green frog, a taxonomic complex that is ubiquitous and presumably relatively tolerant with respect to pollution (Zhelev et al. 2015). However, green frogs were not the only amphibian species present at our study SWPs but European green toads (Bufotes viridis) could also be found (Jumeau et al. 2020). The reason for the overrepresentation of these two species at the SWPs is likely linked to the attractiveness of these 
sites for these species (e.g. nearest site to the wintering habitat; presence of first singing males), rather than to the intrinsic ecological quality of SWPs in a disturbed landscape. Because amphibian species may respond differently to a given stressor (Katz 1975, 1981; Otero et al. 2018), a way to solve and prioritise the question of the intrinsic quality of the SWPs for amphibians requires further consideration, especially because it may also concern the most endangered amphibian species in the area, the European green toad. Finally, we suggest that future studies should address questions concerning the health status of amphibians at SWPS more directly and investigate whether individuals at these sites (presumably more polluted and eutrophic) are more susceptible to disease and parasite load. Internal (e.g. trematodes; Johnson et al. 2007) and external parasites (e.g. leeches; Schalk et al. 2009) might affect the health of numerous amphibian species at SWPs.

To conclude, in a landscape highly fragmented by roads and agricultural fields, where natural wetlands have almost vanished, stormwater ponds (SWPS) could be considered as suitable substitute habitats for adult and sub-adult European green frogs. However, potential physical traps, such as oil removers, have to be modified, to prevent trapping and, potentially, killing amphibians. By contrast, our results for juveniles, known to have hatched at the SWPs investigated, suggest that SWPs are less suitable for the early development of green frogs. It is therefore most likely, that the adult and sub-adult green frogs captured at the SWPS originated from different, more favorable sites. Since a healthy and sufficiently large juvenile population is crucial for population survival, the use of SWPs as habitat will likely not support a viable green frog population. The major function of SWPs for green frogs might be to act as relay sites, allowing frogs to recolonize relict wetlands. The development of specific management measures could also help to improve the quality of SWPs for amphibians. For example, the regular drainage of such ponds during the non-breeding season and the removal of polluted sediment might be an important measure in this context. While further research is clearly needed, a conservation strategy that will preserve existing wetlands and restore former wetlands will be most beneficial to many amphibian species.

\section{Acknowledgements}


527

528

529

530

531

532

533

534

535

536

537

538

539

540

541

542

543

544

545

546

547

548

We thank all the students who participated in this study and two anonymous reviewers for their valuable comments.

\section{Declarations}

Funding

This study was conducted within the framework of the CERISE project and was funded by the French Minister of Ecology (DREAL Grand-Est), the Region Grand-Est, and the Conseil Départemental du Bas-Rhin (CD67). The funders had no role in any aspect of the study and agree to its publication.

5

Conflicts of interest/Competing interests

None of the authors of this manuscript has any potentially competing interests.

\section{Ethics approval}

All experimental protocols for this study complied with national legislation and were approved by the appropriate authorities: “Arrêté Préfectoral n²019-DREAL-EBP0030".

\section{Consent to participate}

All authors participated in the writing of this manuscript.

\section{Consent for publication}

All authors have approved the submission to 'Urban Ecosystems'. 

the corresponding author upon request.

552

\section{Code availability}

554

The codes used with $\mathrm{R}$ software during the current study are available from the corresponding author upon request.

556

\section{Author contributions}

558

All authors approve this version of the manuscript for publication. They agree to be accountable for the aspects of the work that they conducted, and will ensure that any questions related to the accuracy or integrity of any part of their work are appropriately investigated and resolved. AC, JJ, \& YH conceived the study and designed the methods; AC \& ND collected the data; AC \& JJ analysed the data; AC drafted the manuscript with contributions from JJ, ND, ME, JYG \& YH. 
Agence de l'Eau Rhin-Meuse, DREAL. 2016. Programme de mesures du district Rhin.

Alam MZ, Anwar AHMF, Heitz A, Sarker DC. 2018. Improving stormwater quality at source using catch basin inserts. Journal of Environmental Management 228:393-404. Academic Press.

Alex Smith M, M. Green D. 2005. Dispersal and the metapopulation paradigm in amphibian ecology and conservation: are all amphibian populations metapopulations? Ecography 28:110-128. John Wiley \& Sons, Ltd.

Alford R, Bradfield K, Richards S. 1999. Measuring and analyzing developmental instability as a tool for monitoring frog populations. Declines and disappearances of Australian frogs. Environment Australia, Canberra:34-43.

Baird TA, Hranitz JM, Timanus DK, Schwartz AM. 2007. Behavioral attributes influence annual mating success more than morphological traits in male collared lizards. Behavioral Ecology.

Berven KA, Gill DE. 1983. Interpreting Geographic Variation in Life-History Traits. American Zoologist 23:85-97. Oxford Academic.

Bishop CA, Struger J, Shirose L, Dunn L, Campbell GD. 2000. Contamination and Wildlife Communities in Stormwater Detention Ponds in Guelph and the Greater Toronto Area, Ontario, 1997 and 1998 Part II - Contamination and Biological Effects of Contamination. Water Quality Research Journal 35:437-474. IWA Publishing.

Brand AB, Snodgrass JW. 2010. Value of Artificial Habitats for Amphibian Reproduction in Altered Landscapes. Conservation Biology 24:295-301. John Wiley \& Sons, Ltd (10.1111).

Brand AB, Snodgrass JW, Gallagher MT, Casey RE, Van Meter R. 2010. Lethal and sublethal effects of embryonic and larval exposure of Hyla versicolor to stormwater pond sediments. Archives of Environmental Contamination and Toxicology 58:325-331. Springer.

Breno M, Bots J, De Schaepdrijver L, Van Dongen S. 2013. Fluctuating Asymmetry as Risk Marker for Stress and Structural Defects in a Toxicologic Experiment. Birth Defects Research Part B: Developmental and Reproductive Toxicology 98:310-317.

Brischoux F, Lourdais O, Boissinot A, Angelier F. 2018. Influence of temperature, size and confinement on testosterone and corticosterone levels in breeding male spined toads (Bufo spinosus). General and Comparative Endocrinology 269:75-80. Academic Press.

Bryer PJ, Elliott JN, Willingham EJ. 2006. The effects of coal tar based pavement sealer on amphibian development and metamorphosis. Ecotoxicology 15:241-247.

BUFO. 2014. La Liste rouge des Amphibiens menacés en Alsace. BUFO, ODONAT. Document numérique.

Catenazzi A. 2015. State of the world's amphibians. Annual Review of Environment and Resources 40:91-119. Annual Review of Environment and Resources.

Cayuela H et al. 2020. Determinants and Consequences of Dispersal in Vertebrates with 

Complex Life Cycles: A Review of Pond-Breeding Amphibians. The Quarterly Review of Biology 95:1-36. The University of Chicago PressChicago, IL.

Clevenot L, Conan A, Jumeau J. 2020. Utilisation des bassins de rétention des eaux pluviales par la faune aquatique: le cas des amphibiens.

Costa RN, Nomura F. 2016. Measuring the impacts of Roundup Original ${ }^{\circledR}$ on fluctuating asymmetry and mortality in a Neotropical tadpole. Hydrobiologia 765:85-96. Springer International Publishing.

Cushman SA. 2006. Effects of habitat loss and fragmentation on amphibians: A review and prospectus. Biological Conservation 128:231-240. Elsevier BV.

Davidson NC. 2014. How much wetland has the world lost? Long-term and recent trends in global wetland area. Marine and Freshwater Research 65:934. CSIRO.

Dirzo R, Young HS, Galetti M, Ceballos G, Isaac NJB, Collen B. 2014. Defaunation in the Anthropocene. Science (New York, N.Y.) 345:401-6. American Association for the Advancement of Science.

Dorchin A, Shanas U. 2010. Assessment of pollution in road runoff using a Bufo viridis biological assay. Environmental Pollution 158:3626-3633. Elsevier.

Downing RJ, Rytwinski T, Fahrig L. 2015. Positive effects of roads on small mammals: a test of the predation release hypothesis. Ecological Research 30:651-662. Springer-Verlag Tokyo.

Duellman WE, Trueb L. 1994. Biology of amphibians. JHU press.

Duffus ALJ, Cunningham AA. 2010. Major disease threats to European amphibians. The Herpetological Journal 20:117-127. British Herpetological Society.

Duguet R, Melki F, Association A. 2003. Les Amphibiens de France, Belgique et Luxembourg. Biotope.

EEA. 2020. Monitoring CO2 emissions from passenger cars and vans. Page EEA Report.

Egea-Serrano A, Relyea RA, Tejedo M, Torralva M. 2012. Understanding of the impact of chemicals on amphibians: a meta-analytic review. Ecology and Evolution 2:1382-1397.

EPA. 2009. Stormwater wet pond and wetland management guidebook. Center For Watershed Protection:80. Available from https://www3.epa.gov/npdes/pubs/pondmgmtguide.pdf.

Falaschi M, Melotto A, Manenti R, Ficetola GF. 2020. Invasive species and amphibian conservation. Herpetologica 76:216-227. Herpetologist's League Inc.

Finlayson-Pitts BJ, Pitts JN. 1997. Tropospheric air pollution: Ozone, airborne toxics, polycyclic aromatic hydrocarbons, and particles. Science 276:1045-1052. American Association for the Advancement of Science.

Fischer J, Lindenmayer DB. 2007, May. Landscape modification and habitat fragmentation: A synthesis.

Furrer RD, Pasinelli G. 2016. Empirical evidence for source-sink populations: a review on 
Gallagher MT, Snodgrass JW, Brand AB, Casey RE, Lev SM, Van Meter RJ. 2014. The role of pollutant accumulation in determining the use of stormwater ponds by amphibians. Wetlands Ecology and Management 22:551-564. Springer Netherlands.

Gibbons JW et al. 2000, August 1. The global decline of reptiles, deja vu amphibians. American Institute of Biological Sciences.

Grayson KL, De Lisle SP, Jackson JE, Black SJ, Crespi EJ. 2012. Behavioral and physiological female responses to male sex ratio bias in a pond-breeding amphibian. Frontiers in Zoology 9:24. BioMed Central.

Green AJ. 2001. Mass/length residuals: Measures of body condition or generators of spurious results? Ecology 82:1473-1483. Ecological Society of America.

Green DM. 2013. Sex Ratio and Breeding Population Size in Fowler's Toad, Anaxyrus ( = Bufo) fowleri. Copeia 2013:647-652. American Society of Ichthyologists and Herpetologists (ASIH).

Guarino FM, Angelini F, Cammarota M. 1995. A skeletochronological analysis of three syntopic amphibian species from southern Italy. Amphibia-Reptilia 16:297-302.

Guillot H, Boissinot A, Angelier F, Lourdais O, Bonnet X, Brischoux F. 2016. Landscape influences the morphology of male common toads (Bufo bufo). Agriculture, Ecosystems and Environment 233:106-110. Elsevier B.V.

Guo R, Zhang W, Ai S, Ren L, Zhang Y. 2017. Fluctuating asymmetry rather than oxidative stress in Bufo raddei can be an accurate indicator of environmental pollution induced by heavy metals. Environmental Monitoring and Assessment 189. Springer International Publishing.

Hamer AJ, Parris KM. 2011. Local and landscape determinants of amphibian communities in urban ponds. Ecological Applications 21:378-390. John Wiley \& Sons, Ltd.

Hassall C, Anderson S. 2015. Stormwater ponds can contain comparable biodiversity to unmanaged wetlands in urban areas. Hydrobiologia 745:137-149. Springer International Publishing.

Indermaur L, Winzeler T, Schmidt BR, Tockner K, Schaub M. 2009. Differential resource selection within shared habitat types across spatial scales in sympatric toads. Ecology 90:3430-3444.

Janin A, Léna JP, Joly P. 2011. Beyond occurrence: Body condition and stress hormone as integrative indicators of habitat availability and fragmentation in the common toad. Biological Conservation 144:1008-1016.

Joly P. 2019. Behavior in a Changing Landscape: Using Movement Ecology to Inform the Conservation of Pond-Breeding Amphibians. Frontiers in Ecology and Evolution 7:155. Frontiers.

Johnson PTJ, Chase JM, Dosch KL, Hartson RB, Gross JA, Larson DJ, Sutherland DR, Carpenter SR. 2007. Aquatic eutrophication promotes pathogenic infection in amphibians. Proceedings of the National Academy of Sciences of the United States of America 

104:15781-15786. National Academy of Sciences.

Jumeau J, Lopez J, Morand A, Petrod L, Burel F, Handrich Y. 2020. Factors driving the distribution of an amphibian community in stormwater ponds: a study case in the agricultural plain of Bas-Rhin, France. European Journal of Wildlife Research 66:33. Springer.

Katz U. 1975. NaCl adaptation in Rana ridibunda and a comparison with the euryhaline toad Bufo viridis. Journal of Experimental Biology 63:763-773. The Company of Biologists Ltd.

Katz U. 1981. The effect of salt adaptation and amiloride on the in vivo acid-base status of the euryhaline toad Bufo viridis. Journal of Experimental Biology 93:93-99. The Company of Biologists Ltd.

Kik M, Martel A, Sluijs AS van der, Pasmans F, Wohlsein P, Gröne A, Rijks JM. 2011. Ranavirusassociated mass mortality in wild amphibians, The Netherlands, 2010: A first report. Veterinary Journal 190:284-286. W.B. Saunders.

Kyriakopoulou-Sklavounou P, Loumbourdis N. 1990. Annual Ovarian Cycle in the Frog, Rana ridibunda, in Northern Greece. Journal of Herpetology 24:185. JSTOR.

Le Viol I, Chiron F, Julliard R, Kerbiriou C. 2012. More amphibians than expected in highway stormwater ponds. Ecological Engineering 47:146-154.

Lesbarrères D, Lodé T. 2002. Influence de facteurs environnementaux sur la reproduction de Rana dalmatina (Anura, Ranidae): implications pour sa conservation. Bulletin de la Société herpétologique de France 104:62-71.

Leung B, Forbes MR, Houle D. 2000. Fluctuating asymmetry as a bioindicator of stress: Comparing efficacy of analyses involving multiple traits. American Naturalist 155:101115.

Loman J, Madsen T. 2010. Sex ratio of breeding Common toads (Bufo bufo)-influence of survival and skipped breeding. Amphibia-Reptilia 31:509-524. Brill.

Mander Ü, Mitsch WJ. 2009, February 9. Pollution control by wetlands. Ecological Engineering 35:153-158.

Martinez IP, Álvarez R, Herráez MP. 1996. Growth and metamorphosis of Rana perezi larvae in culture: Effects of larval density. Aquaculture 142:163-170. Elsevier.

Martinez IP, Herráez MP, Álvarez R. 1993. Optimal level of dietary protein for Rana perezi Seoane larvae. Aquaculture Research 24:271-278.

Martins FMS, Oom M do M, Rebelo R, Rosa GM. 2013. Differential effects of dietary protein on early life-history and morphological traits in natterjack toad (Epidalea calamita) tadpoles reared in captivity. Zoo Biology 32:457-462. John Wiley \& Sons, Ltd.

Masello JF, Quillfeldt P. 2003. Body size, body condition and ornamental feathers of Burrowing Parrots: Variation between years and sexes, assortative mating and influences on breeding success. Emu 103:149-161. Taylor \& Francis.

Maxwell SL, Fuller RA, Brooks TM, Watson JEM. 2016, August 10. Biodiversity: The ravages of guns, nets and bulldozers. Nature Publishing Group. 
Metcalfe CD, Nagabhatla N, Fitzgerald SK. 2018. Multifunctional Wetlands: Pollution Abatement by Natural and Constructed Wetlands. Pages 1-14.

Miaud C, Guyetant R, Elmberg J. 1999. Variations in life-history traits in the common frog Rana temporaria (Amphibia: Anura): a literature review and new data from the French Alps. Journal of Zoology 249:61-73. Wiley.

Miaud C. 2014. Protocole d’hygiène pour le contrôle des maladies des amphibiens dans la nature à destination des opérateurs de terrain.

Oertli B, Parris KM. 2019. Review: Toward management of urban ponds for freshwater biodiversity. Ecosphere 10. Wiley-Blackwell.

Otero MA, Pollo FE, Grenat PR, Salas NE, Martino AL. 2018. Differential effects on life history traits and body size of two anuran species inhabiting an environment related to fluorite mine. Ecological Indicators 93:36-44. Elsevier B.V.

Pagano A, Crochet PA, Graf J-D, Joly P, Lode T. 2001. Distribution and habitat use of water frog hybrid complexes in France. Global Ecology and Biogeography 10:433-441. John Wiley \& Sons, Ltd.

Palmer AR, Strobeck C. 1986. Fluctuating Asymmetry: Measurement, Analysis, Patterns. Annual Review of Ecology and Systematics 17:391-421.

Parris KM. 2006. Urban amphibian assemblages as metacommunities. Journal of Animal Ecology.

Patrelle C, Ohst T, Picard D, Pagano A, Sourice S, Dallay M-G, Plötner J. 2011. A new PCR-RFLPbased method for an easier systematic affiliation of European water frogs. Molecular Ecology Resources 11:200-205. John Wiley \& Sons, Ltd.

Peter A-KH. 2001. Dispersal Rates and Distances in Adult Water Frogs, Rana lessonae, $R$. ridibunda, and Their Hybridogenetic Associate R. esculenta. Allen PressHerpetologists' League.

Price SJ, Garner TWJ, Nichols RA, Balloux F, Ayres C, et al. 2014. Collapse of amphibian communities due to an introduced Ranavirus. Curr. Biol. 24:2586-2591.

Pulliam HR. 1988. Sources, Sinks, and Population Regulation. The American Naturalist 132:652-661. University of Chicago Press.

Quaranta A, Bellantuono V, Cassano G, Lippe C. 2009. Why Amphibians Are More Sensitive than Mammals to Xenobiotics. PLoS ONE 4:e7699.

Runge JP, Runge MC, Nichols JD. 2006. The role of local populations within a landscape context: defining and classifying sources and sinks. The American naturalist 167:925-38.

Salice CJ. 2012. Multiple Stressors and Amphibians: Contributions of Adverse Health Effects and Altered Hydroperiod to Population Decline and Extinction. Journal of Herpetology 46:675-681.

Sanuy D, Avrillier J-N, Miaud C. 2000. Terrestrial movements of the natterjack toad Bufo calamita (Amphibia, Anura) in a semi-arid, agricultural landscape. Amphibia-Reptilia 21:357-369. Brill. 
Schalk G, Forbes MR, Weatherhead PJ. 2002. Developmental plasticity and growth rates of green frog (Rana clamitans) embryos and tadpoles in relation to a leech (Macrobdella decora) predator. Copeia 2002:445-449.

Scher O, Chavaren P, Despreaux M, Thiéry A. 2004. Highway stormwater detention ponds. Archives des Sciences 57:121-130.

Schulte-Hostedde Al, Zinner B, Millar JS, Hickling GJ. 2005. Restitution of mass-size residuals: Validating Body Condition Indices. Ecology 86:155-163.

Schwarzkopf L, Alford RA. 1996. Desiccation and Shelter-Site Use in a Tropical Amphibian: Comparing Toads with Physical Models. Functional Ecology 10:193. JSTOR.

Seebacher F, Alford RA. 2002. Shelter Microhabitats Determine Body Temperature and Dehydration Rates of a Terrestrial Amphibian (Bufo marinus). Journal of Herpetology 36:69. JSTOR.

Semlitsch RD, Scott DE, Pechmann JHK. 1988. Time and Size at Metamorphosis Related to Adult Fitness in Ambystoma talpoideum. Ecology 69:184-192. John Wiley \& Sons, Ltd.

Shine R. 1979. Sexual Selection and Sexual Dimorphism in the Amphibia. Copeia 1979:297. JSTOR.

Sievers M. 2017. Sand quarry wetlands provide high-quality habitat for native amphibians. Web Ecology.

Sievers M, Parris KM, Swearer SE, Hale R. 2018. Stormwater wetlands can function as ecological traps for urban frogs. Ecological Applications 28:1106-1115. John Wiley \& Sons, Ltd.

Sievers M, Hale R, Swearer SE, Parris KM. 2019. Frog occupancy of polluted wetlands in urban landscapes. Conservation Biology 33:389-402. Blackwell Publishing Inc.

Snodgrass JW, Casey RE, Joseph D, Simon JA. 2008. Microcosm investigations of stormwater pond sediment toxicity to embryonic and larval amphibians: Variation in sensitivity among species. Environmental Pollution 154:291-297.

Snodgrass JW, Moore J, Lev SM, Casey RE, Ownby DR, Flora RF, Izzo G. 2017. Influence of Modern Stormwater Management Practices on Transport of Road Salt to Surface Waters. Environmental Science \& Technology 51:4165-4172. American Chemical Society.

Stuart SN, Chanson JS, Cox NA, Young BE, Rodrigues ASL, Fischman DL, Waller RW. 2004. Status and trends of amphibian declines and extinctions worldwide. Science (New York, N.Y.) 306:1783-6. American Association for the Advancement of Science.

Taziki M, Ahmadzadeh H, Murry MA, Lyon SR. (n.d.). Nitrate and Nitrite Removal from Wastewater using Algae. Bentham Science Publishers.

Van der Ree R, Smith DJ, Daniel J, Grilo C. 2015. Handbook of road ecology.

Waelti MO, Reyer H-U. 2007. Food supply modifies the trade-off between past and future reproduction in a sexual parasite-host system (Rana esculenta, Rana lessonae). Oecologia 152:415-424. Springer. 
Wells KD. 1977. The social behaviour of anuran amphibians. Animal Behaviour 25:666-693.

Whitman DW. 2008. The significance of body size in the Orthoptera: a review. Journal of Orthoptera Research 17:117-134. Pensoft Publishers.

Wilbur HM. 1980. Complex Life Cycles. Annual Review of Ecology and Systematics 11:67-93.

Zabel F, Delzeit R, Schneider JM, Seppelt R, Mauser W, Václavík T. 2019. Global impacts of future cropland expansion and intensification on agricultural markets and biodiversity. Nature Communications.

Zhelev ZM, Popgeorgiev GS, Arnaudov AD, Georgieva KN, Mehterov NH. 2015. Fluctuating asymmetry in Pelophylax ridibundus (Amphibia: Ranidae) as a response to anthropogenic pollution in south Bulgaria. Archives of Biological Sciences 67:1009-1023.

Zhelev Z, Tsonev S, Georgieva K, Arnaudova D. 2018. Health status of Pelophylax ridibundus (Amphibia: Ranidae) in a rice paddy ecosystem in Southern Bulgaria and its importance in assessing environmental state: haematological parameters. Environmental Science and Pollution Research 25:7884-7895. Springer Verlag.

Zhelev ZM, Tsonev S V., Angelov M V. 2019. Fluctuating asymmetry in Pelophylax ridibundus meristic morphological traits and their importance in assessing environmental health. Ecological Indicators 107. Elsevier B.V.

Figures

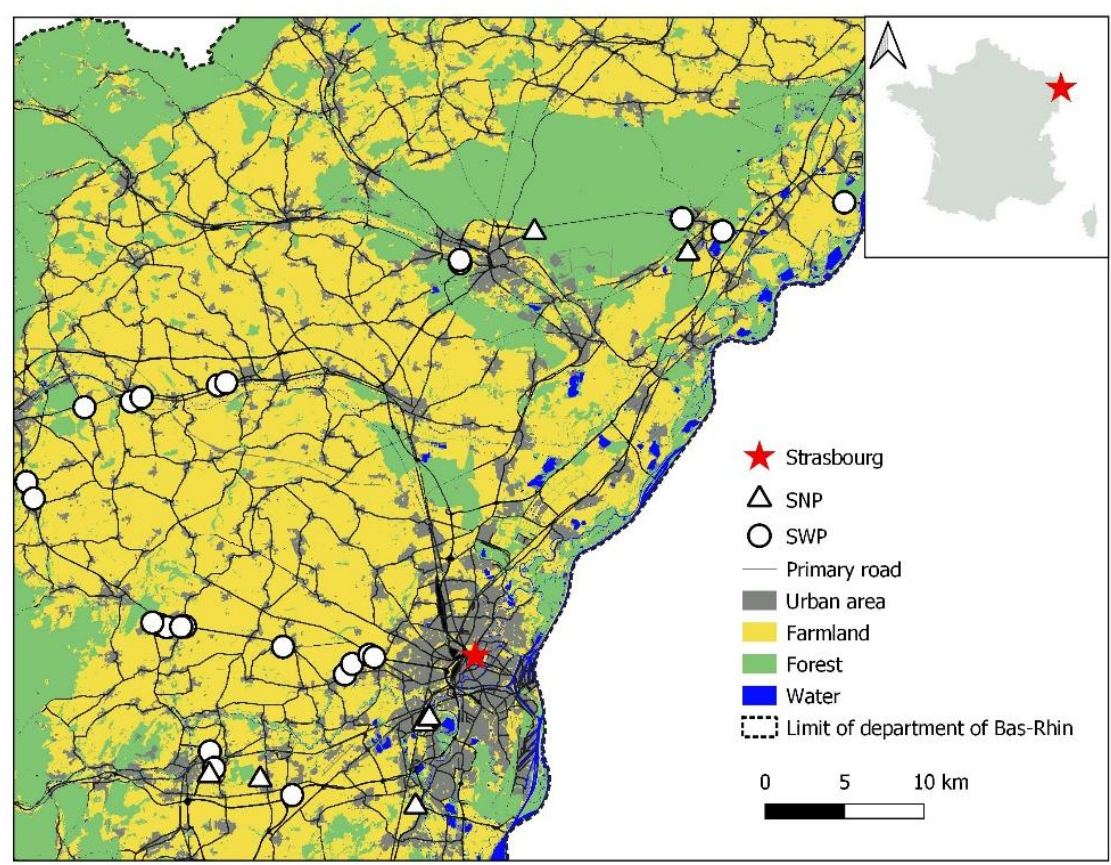

Figure 1: Study area and pond locations. 

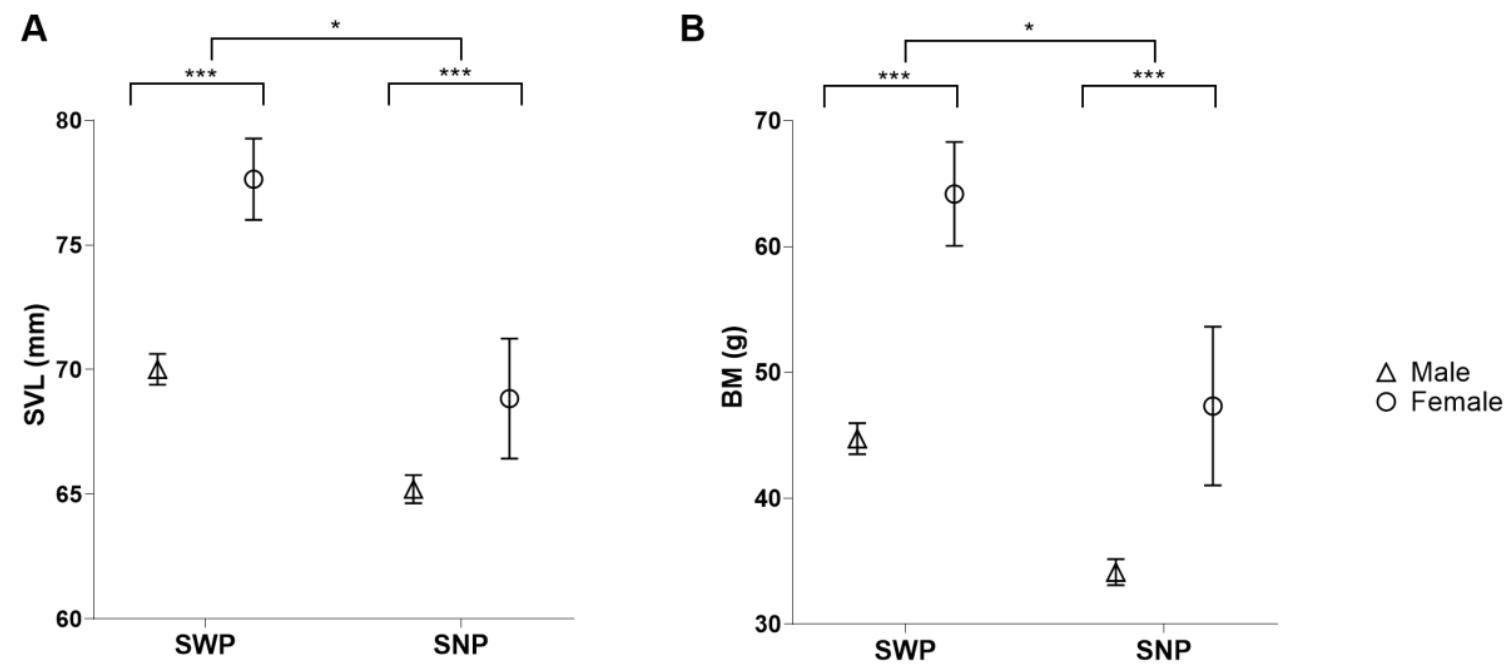

Figure 2: Comparison (means \pm SEM) of body length (Snout Vent Length, SVL; A) and body mass (BM; B) between adult male (triangles) and adult female (circles) European green frogs (Pelophylax sp.) captured in SWPs $\left(N_{\sigma^{\prime}}=250 ; N_{0}=58\right)$ and SNPs $\left(N_{\gamma^{\prime}}=107 ; N_{q}=27\right)$. Females were larger and heavier than males in both pond types (ANOVA, $* * * P<0.001$ ). Individuals caught at SWPs were larger and heavier than individuals caught in SNPs (Wilcoxon test, * $\mathrm{P}<0.05$ ).

830 


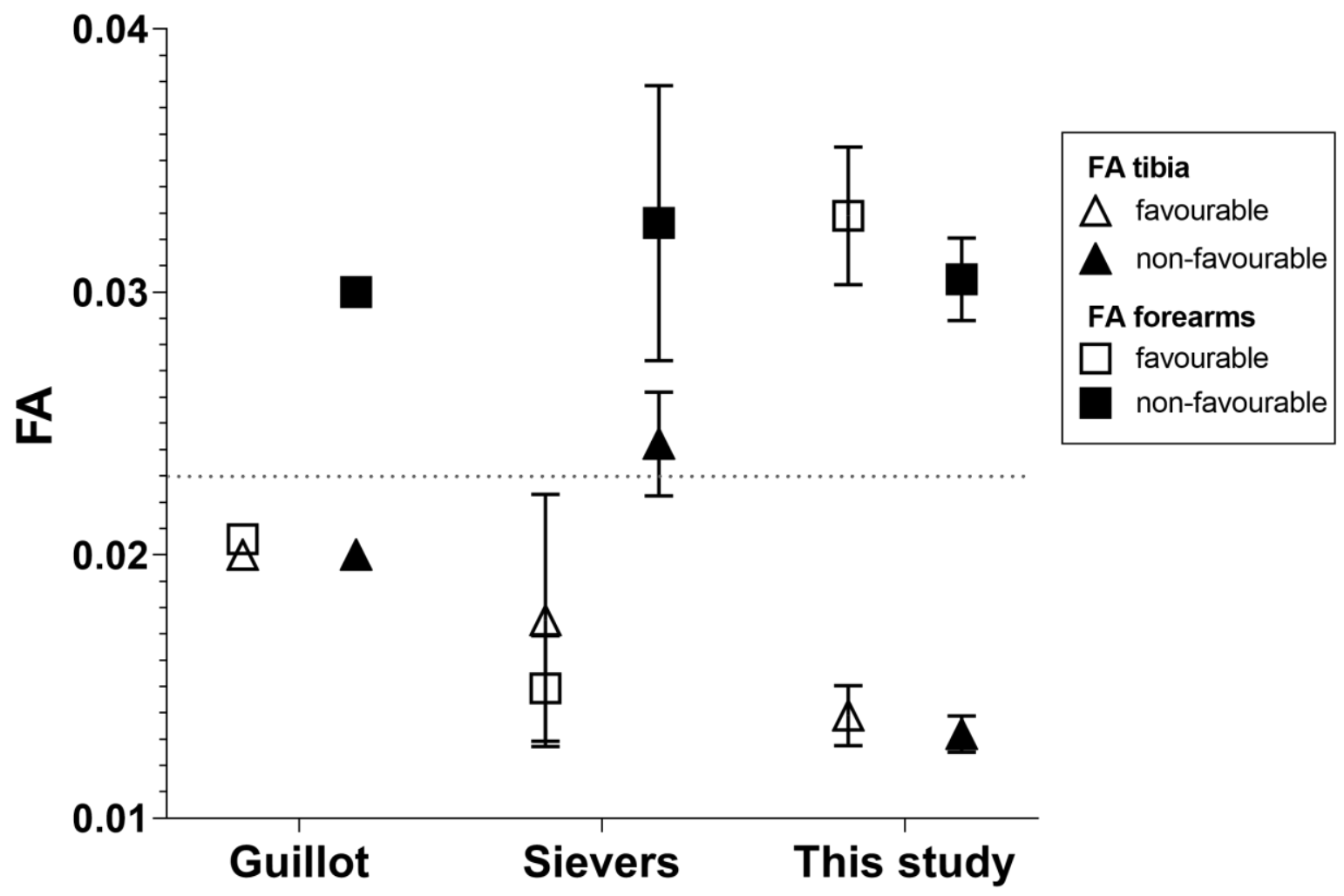

Figure 3: Fluctuating asymmetry (FA) based on forearm (squares) and tibia (triangles) measurements in amphibian species inhabiting contrasting environments (favourable in white and non-favourable in black) in agricultural areas (common toad, Guillot et al. 2016), wetlands (common eastern froglet, Sievers 2017) and road landscapes (European green frog, this study). The horizontal dashed line indicates a hypothetical threshold of FA common for all 3 studies and emphasizes the difficulties associated with using FA indices in interspecific studies.

\section{Tables}

Tab. 1: Environmental parameters of SWPs used to test for potential effects on fitness indicators of male European green frogs (Pelophylax sp.)

\begin{tabular}{|c|c|c|c|c|}
\hline Conception of SWPS & $\begin{array}{l}\text { Water } \\
\text { pollutants }\end{array}$ & $\begin{array}{l}\text { Immediate landscape } \\
\text { (500 m radius) }\end{array}$ & Distant landscape (5000 m radius) & Biotic elements \\
\hline Age (year) & Nitrogen $(\mathrm{mg} / \mathrm{l})$ & $\begin{array}{l}\text { Presence of crop } \\
\text { field }\end{array}$ & Surface area of crop fields $\left(\mathrm{m}^{2}\right)$ & $\begin{array}{l}\text { Green frog } \\
\text { abundance }\end{array}$ \\
\hline Presence of oil remover & Chlorine (mg/l) & Presence of forest & Surface area of forests $\left(\mathrm{m}^{2}\right)$ & Presence of algae \\
\hline $\begin{array}{l}\text { Nearest road distance } \\
\text { (m) }\end{array}$ & Copper (mg/l) & Presence of hedges & Surface area of grassland $\left(\mathrm{m}^{2}\right)$ & $\begin{array}{l}\text { Presence of aerial } \\
\text { vegetation }\end{array}$ \\
\hline $\begin{array}{l}\text { Presence of slope }<30^{\circ} \\
\text { Volume }\left(\mathrm{m}^{3}\right)\end{array}$ & & Presence of a road & $\begin{array}{l}\text { Surface area of highway network } \\
\left(\mathrm{m}^{2}\right) \\
\text { Surface of wetland }\left(\mathrm{m}^{2}\right)\end{array}$ & $\begin{array}{l}\text { Amphibian } \\
\text { species richness }\end{array}$ \\
\hline Volume $\left(\mathrm{m}^{3}\right)$ & & & $\begin{array}{l}\text { Surface area of notable wetland } \\
\left(\mathrm{m}^{2}\right)\end{array}$ & \\
\hline
\end{tabular}


Tab. 2: Biometric measurements (means \pm SEM) for four different groups of European green frogs, captured in SWPs and SNPS

\begin{tabular}{|c|c|c|c|c|c|}
\hline & & Males & Females & Sub-adults & Juveniles \\
\hline \multirow{5}{*}{$\begin{array}{l}\text { SWPs } \\
(n=25)\end{array}$} & $\mathrm{SVL}(\mathrm{mm})$ & $70.0 \pm 0.6$ & $77.6 \pm 1.6$ & $50.2 \pm 0.7$ & $25.1 \pm 0.4$ \\
\hline & $\mathrm{BM}(\mathrm{g})$ & $44.7 \pm 1.2$ & $64.1 \pm 4.2$ & $15.1 \pm 0.7$ & $1.9 \pm 0.1$ \\
\hline & $B C I^{(E-3)}$ & $1.3 \pm 2.5$ & $8.7 \pm 5.1$ & $4.2 \pm 4.5$ & $-9.2 \pm 5,0$ \\
\hline & AF Tibias ${ }^{(E-3)}$ & $13 \pm 0.7$ & $12 \pm 1.3$ & $13 \pm 1.2$ & $21 \pm 2.2$ \\
\hline & AF Forearms ${ }^{(E-3)}$ & $31 \pm 1.6$ & $32 \pm 2.9$ & $34 \pm 3.6$ & $53 \pm 4.9$ \\
\hline \multirow{5}{*}{$\begin{array}{l}\text { SNPs } \\
(n=9)\end{array}$} & $\mathrm{SVL}(\mathrm{mm})$ & $65.2 \pm 0.6$ & $68.8 \pm 2.4$ & $50.6 \pm 0.8$ & $27.9 \pm 1.1$ \\
\hline & $\mathrm{BM}(\mathrm{g})$ & $34.1 \pm 1.0$ & $47.3 \pm 6.3$ & $15.9 \pm 0.8$ & $2.4 \pm 0.3$ \\
\hline & $\mathrm{BCl}^{(\mathrm{E}-3)}$ & $-0.8 \pm 2.8$ & $-7.3 \pm 4.9$ & $-7.5 \pm 5.9$ & $38 \pm 10$ \\
\hline & AF Tibias ${ }^{(E-3)}$ & $14 \pm 1.1$ & $13 \pm 1.8$ & $12 \pm 1.5$ & $16 \pm 3.5$ \\
\hline & $A F$ Forearms ${ }^{(E-3)}$ & $33 \pm 2.6$ & $34 \pm 4.9$ & $34 \pm 3.9$ & $33 \pm 4.7$ \\
\hline
\end{tabular}

847

848

Tab. 3: Statistical comparisons for biometric measurements of European green frogs (Pelophylax sp.) captured in SWPs versus 850 SNPS

\begin{tabular}{|c|c|c|c|c|c|c|c|c|c|c|c|c|}
\hline \multirow[b]{2}{*}{ Measure } & \multicolumn{3}{|c|}{ Males ( $n=357)$} & \multicolumn{3}{|c|}{ Females $(n=85)$} & \multicolumn{3}{|c|}{ Sub-adults ( $n=112$ ) } & \multicolumn{3}{|c|}{$\begin{array}{c}\text { Juveniles }(\mathrm{n}=77) \\
852\end{array}$} \\
\hline & $\chi^{2}$ & $\mathrm{df}$ & $p$ & $\chi^{2}$ & $d f$ & $p$ & $\chi^{2}$ & $d f$ & $p$ & $\chi^{2}$ & $\mathrm{df}$ & $\begin{array}{r}p \\
853 \\
\end{array}$ \\
\hline SVL & 5.76 & 1 & 0.016 & 3.98 & 1 & 0.046 & 0.15 & 1 & 0.69 & 5.12 & 1 & $\begin{array}{l}0.02 \\
854\end{array}$ \\
\hline BM & 6.04 & 1 & 0.014 & 5.18 & 1 & 0.022 & 0.43 & 1 & 0.51 & 3.04 & 1 & $\begin{array}{l}0.08 \\
855\end{array}$ \\
\hline $\mathrm{BCl}$ & 0.05 & 1 & 0.81 & 1.75 & 1 & 0.18 & 0.94 & 1 & 0.33 & 5.97 & 1 & $\begin{array}{l}0.01 \\
856\end{array}$ \\
\hline FA Tibias & 0.25 & 1 & 0.61 & 0.11 & 1 & 0.73 & 0.69 & 1 & 0.41 & 0.74 & 1 & $857^{0.39}$ \\
\hline FA forearms & 0.37 & 1 & 0.54 & 0.18 & 1 & 0.66 & $4 \mathrm{E}-4$ & 1 & 0.98 & 1.86 & 1 & $858^{0.17}$ \\
\hline
\end{tabular}


Tab. 4: Statistical outputs from Linear Model Analysis testing for relationships between male frog biometric variables and 864 environmental parameters at SWPs

\begin{tabular}{|c|c|c|c|c|}
\hline \multirow[b]{2}{*}{ Dependant variable } & \multicolumn{4}{|c|}{ LM } \\
\hline & Parameter & Estimate $(\beta)$ & SE & $P$ \\
\hline \multirow[t]{4}{*}{ SVL } & (intercept) & 73.98 & 1.55 & $* * *$ \\
\hline & Surface crops $5000 \mathrm{~m}$ & 4.92 & 2.01 & $*$ \\
\hline & Surface forest $5000 \mathrm{~m}$ & 4.12 & 1.72 & $*$ \\
\hline & Surface notable wetlands $5000 \mathrm{~m}$ & -2.93 & 0.97 & $*$ \\
\hline \multirow[t]{3}{*}{$\mathrm{BCl}$} & (intercept) & $8.1 \mathrm{E}-03$ & 4.1E-03 & ns \\
\hline & Presence of an oil remover & $-2.3 \mathrm{E}-02$ & $3.2 \mathrm{E}-03$ & $* *$ \\
\hline & Surface grassland $5000 \mathrm{~m}$ & $-1.2 \mathrm{E}-02$ & $6.3 \mathrm{E}-03$ & $* *$ \\
\hline \multirow[t]{3}{*}{ FA forearms } & (intercept) & $2.9 \mathrm{E}-02$ & $1.3 \mathrm{E}-03$ & $* * *$ \\
\hline & Surface grassland $5000 \mathrm{~m}$ & $-3.6 \mathrm{E}-03$ & $1.4 \mathrm{E}-03$ & $*$ \\
\hline & Surface notable wetlands $5000 \mathrm{~m}$ & $-4.5 E-03$ & $1.4 \mathrm{E}-03$ & $* *$ \\
\hline FA tibias $\sim 1$ & & & & \\
\hline
\end{tabular}

866 